\title{
CHAPTER 7. France: electoral necessity and presidential leadership beyond parties
}

In Torbjörn Bergman, Hanna Back, and Johan Hellström (eds.), “Coalition Governance in Western Europe”, Oxford University Press, 2021, pp. 205-246

Scholars of the French polity have seldom studied coalition-making between political parties (Bué \& Desage 2009). ${ }^{1}$ In classic textbooks and handbooks dealing with French politics and institutions, the word "coalition" hardly appears at all (e.g., Chevallier et al. 2004; Safran 2008; Elgie et al. 2016). The lack of interest might stem from the peculiar way coalitions are formed, maintained and terminated: in France, where coalition politics work differently from most other west-European parliamentary democracies (Thiébault 2003). There are two main reasons for this specificity.

First, due to the majoritarian two-round electoral system, parliamentary elections often result in a one-party parliamentary majority, which leaves little room to postelectoral coalition bargaining. Coalition agreements mostly take place prior to elections, and mostly consist of pre-electoral deals in which the coalition's senior party grant a few seats to its partner after both parties agree on a laconic policy document. A party's prospects to take part in a government coalition hence depends on its proximity to one of

\footnotetext{
${ }^{1}$ This chapter is based on the analysis of archive material and interviews. We have been able to retrieve several coalition agreements, data on election outcomes and the composition of the assembly (taken in particular from the Journal Officiel and from the government and National Assembly online archives, and the Comparative Political Data Set (Armingeon et al. 2019), press archives from Le Monde (using Lexis Nexis), and also used information gathered in Wikipedia. We also led 17 semi-structured interviews with (former) party leaders, ministers from all governments since 1981, members from some governments' parliamentary majority and chief advisers.
} 
the big government parties. These have traditionally been the successive right-wing parties in the Gaullist tradition and the Socialist party; and since 2017 Emmanuel Macron's LREM. In a highly bipolar party system, this means being close to those parties along the Left-Right division and within a realm of acceptability, which until now has excluded the far right. Moreover, a party must have some "political weight", which can be reflected in its number of parliamentary seats, its performances at the last presidential or other second-order elections, or its past alliances.

Second, in a semi-presidential regime where the executive enjoys increasing powers (Grossman \& Sauger 2009), coalition members play a small role compared to the president (or the prime minister in times of cohabitation $^{2}$ ). Cabinet formation and portfolio allocation rest in the discretionary power of the chief of the executive and no real (in)formal coordination or negotiation takes place. The chief of the executive also exclusively presides over government's reshuffles, unless - a very rare case - a party decides to leave the coalition. Cabinet termination, as a result, mostly takes place following new national (presidential or parliamentary) elections.

Noël Mamère, one of the leaders of the (left-ecologist) Green party and candidate to the 2002 presidential election, argued in our interview that French coalitions were nothing like "government coalitions in the Anglo-Saxon or German sense of the term". Rather, it amounted to "electoral agreements linked to the electoral system constraining small parties to be in the hand of a mainstream party needing allies to show its openness during elections. [...] In order to foster the acceptance of the electoral agreement, junior parties usually obtain only one or two emblematic policy concessions". In strict definitional terms, it makes sense to speak of coalition politics (and to include France in a comparative

\footnotetext{
${ }^{2}$ Power sharing between the president and a parliamentary majority.
} 
volume on government coalitions!) insofar as this political system features political parties that sometimes form coalition cabinets. However, as will be discussed in this chapter, French coalition politics does not imply joint structured agreements and stable coalition formation and governance mechanisms, as is common in pure parliamentary systems. It is rather based on bilateral and often informal agreements between one main party and one or several separate junior partners. More generally, given the power asymmetries between the main coalition party and its junior partners, France can be characterized as an extreme case of dominant Prime Minister model. The chief of the executive, i.e., the president in absence of cohabitation, predominates (Dunleavy and Rhodes 1990; Laver and Shepsle 1996; Bergman et al. forthcoming; see also chapter 2 in this volume). As we will see, he has very large autonomy in coalition-building and in coalition governance, leaving single ministers (and to an even stronger extent junior coalition parties) virtually no leeway to shape government policies against his position.

Over the last two decades, France has undergone major institutional and political transformations that have reinforced those dynamics. At the institutional level, the synchronization of presidential and legislative elections has increased the weight of the president in coalition bargaining and management. The party system has also evolved considerably. Both traditional governing parties - the social-democratic Parti Socialiste (PS) and the conservative Les Républicains (LR) - have suffered a severe decline. In parallel, two strong challengers have become fore-runners: the far-right Rassemblement national (formerly Front national) and, in very recent times, the break-through of $L a$ République En Marche (LREM), a catch-all organization with liberal stances, gathering former members of the PS and LR around Emmanuel Macron after his 2017 presidential 
victory. These changes have increased the dimensionality of the political space but have left minor parties as powerless as before in terms of coalition bargaining.

\section{The institutional setting}

In France, coalition building and coalition management takes place within a series of constraints linked to several institutional features. The political system is semipresidential, with an increasingly strong president and asymmetrical bicameralism. Both presidential and legislative elections lead to the formation of a new government. The head of State (the president) has the exclusive power of nominating the prime minister (art. 8, al. 1 of the constitution ${ }^{3}$ ). There is de jure no restriction to this power but there is a strong norm that the prime minister should stem from the party that has a parliamentary majority ${ }^{4}$. If no party obtains an absolute majority - a rare case -, the president approaches the leader from the party with the largest seat share. The French constitution foresees that the prime minister then proposes a list of ministers to the president who nominates them by presidential decrees, countersigned by the prime minister (art. 8, al. 2). Note that except the references to the functions of prime minister and of minister of justice (art. 65), the constitution does not provide any indication regarding the number of ministers and the allocation of competences.

\footnotetext{
${ }^{3}$ Following this article, "the President of the Republic nominates the Prime minister. He terminates his functions when the Prime minister presents the government's resignation. Following the proposition of the Prime minister, he nominates the other members of government and terminates their functions." (authors' translation).

${ }^{4}$ When a new legislative majority different from the presidential majority is elected, the president choses a PM from this new majority, which leads to cohabitation. Note that, in contrast to countries with symmetrical bicameralism, government is only responsible to the National Assembly (lower house) and not to the Senate, so that bicameralism does not significantly affect French coalition politics. For a comparison between France and Italy in this respect, see di Virgilio et al (2015).
} 
Over the first decades of the Fifth Republic, French politics were dominated by a coalition between centrist and right-wing parties (see Table 7.1a below). Presidential and legislative elections were systematically desynchronized but came up with rather stable results with both center-right parties getting a strong majority. Since 1981, by contrast, frequent political alternations between left and right have taken place both at the presidency and in government. In this context, Socialist President François Mitterrand dissolved the National Assembly after both the 1981 and 1988 elections, in order to obtain a parliamentary majority. Because of the shorter parliamentary term, he had to face parliamentary elections (in 1986 and in 1993), which his party (PS) lost, resulting in two phases of cohabitation. In 1995, the newly elected president Jacques Chirac already had a parliamentary majority but provoked legislative elections in 1997, which his conservative party RPR and its allies lost, causing a third episode of cohabitation.

Since 2002, the presidential term has been reduced to 5 years, which led to the alignment of presidential and legislative electoral cycles. In this context, electorally induced coalition-building has become less frequent and more regular (it takes place every five years, following national elections). The 2002 reform also gives more weight to the presidential election, which takes place first: since 2002, legislative elections have granted a strong majority to the coalition of parties supporting the president. This alignment of presidential and legislative elections had important consequences on government, as it translated into the disappearance of cohabitations. The relative weight of the president and the Prime minister in shaping coalition politics - especially through the appointment of ministers (Montay 2013; Sponchiado 2017) - used to depend on whether, or not, there was a cohabitation (Duverger 1978). When the prime minister and the President belong to the same party, the president is, in practice, free to choose the 
prime minister, and he will be prevalent in coalition bargaining. By contrast, in times of cohabitation, the prime minister had the most say (Conley 2007) $)^{5}$ The reduction of the presidential term to 5 years has strengthened the role of the president, who is now the leader of coalition-negotiations (Duverger 2004, chapter IV; François 2011) ${ }^{6}$.

Since governmental coalitions are responsible to the National assembly, the twoballot majority electoral system used for national elections crucially shapes coalition politics. France confirms Golder's (2005) finding that disproportional systems encourage pre-electoral coalitions in party systems with a sufficiently large number of parties (see also Duverger 1954). Importantly, this system favors the biggest parties - who long remained the only ones having a chance to maintain themselves in the second round. At the presidential election, smaller parties are disadvantaged by the run-off voting system. At parliamentary elections, for which only candidates receiving the vote of at least $12.5 \%$ of registered voters can run in the second round, smaller parties rely on pre-electoral alliances to access parliament. Mainstream parties accept not to run in a negotiated number of districts, in order to allow some smaller parties' candidates to make it to the second round and have a chance to get elected. This offers main government parties strong bargaining power towards smaller parties, while creating strong incentives for all parties to agree on electoral alliances (Golder 2006; see Andolfatto \& Greffet 2008 for the example of the French Communist party). At the party level, it also deters dissidents from

\footnotetext{
${ }^{5}$ The president keeps nonetheless a veto. There are historical examples of presidents rejecting the prime minister's choice and asking him/her to choose someone else (the example of Mitterrand regarding the choice of the ministers of foreign affairs and defence is cited in Adler 2015; after Chirac became president in 1995, he also used his veto during the formation of the Jospin government in 1997). However, this veto was exerted regarding individual persons and not regarding coalition formation.

${ }^{6}$ The attempt to gather as many components as possible of the centrist and right-wing conservative parties in one single party, the Union pour un movement populaire (UMP), created in 2002 between the presidential and the legislative elections to provide President Jacques Chirac with a majority, can also be seen as a consequence of this new institutional logic (Haegel 2012). Even if this did not succeed in the long-term, it had implications on coalition-building in the 2000s.
} 
splitting, as a tiny party has no chance to achieve representation at the national level (Gallagher \& Mitchell 2008).

In sum, the majoritarian electoral system, associated to the synchronization of presidential and legislative elections, gives huge leverage to the two largest parties during the campaign and, after the election, to the de facto leader of the winning party, the president.

\section{The party system and the actors}

The mainstream parties' predominance that is induced by the institutions of the Fifth Republic is challenged by the growing fragmentation of the French party system. However, while this is important for representation and politics in general, this has had little impact, so far, on coalition politics in cabinets.

\section{Party System Change}

An overview of the evolution of the relative strength of parties can be gathered from the distribution of parliamentary seats in Table 7.1a. The first decades of the fifth Republic witnessed the progressive structuration of an initially highly fragmented party system inherited from the fourth Republic around two main blocs (Evans 2003). The right-wing bloc remained predominant until 1981. Until 1974, this bloc was organized around the the party (UNR, then UDR), a conservative party in direct filiation with Fifth Republic's founder and first president Charles De Gaulle. Gaullists benefited from the support from most non-Gaullist (more liberal) right-wing MPs, gathered in Valery Giscard d'Estaing's 
parliamentary group Independent Republicans ${ }^{7}$. As discussed below, the left-wing block also progressively structured itself around the Socialist party (PS). Each bloc was relatively stable, but subject to internal competition (on the left, between Communists and Socialists; on the right, between centrist/moderate and conservative parties), so that Duverger (1985) spoke of a quadrille bipolaire.

[TABLE 7.1a about here]

1981 marks a turning point in French political history. After decades of exclusive predominance of centre-right coalitions, the Socialist candidate François Mitterrand won the presidential election and, after he dissolved the National Assembly, obtained an absolute parliamentary majority. The PS initially formed a surplus coalition government with the Communists, who left government in 1984 because of major divergences on macroeconomic policies. Since 1981, France has experienced frequent political alternations, with coalitions led by either the PS or the main conservative party (successively named RPR, UMP and LR). The 1986 parliamentary elections led to the first experience of cohabitation between a Socialist president and a RPR-UDF coalition government led by Jacques Chirac. In 1988, François Mitterrand was reelected, immediately dissolved the National Assembly, but the PS did not control a majority of seats and built a single-party minority government facing opposition both from the Communists and from center-right parties. The 1993 legislative elections gave the RPRUDF alliance a parliamentary majority, which resulted in a second cohabitation between

\footnotetext{
${ }^{7}$ V. Giscard d'Estaing later founded a political party of its own, the Union pour la démocratie française (UDF) gathering multiple center-right non-gaullist organizations. Between 1978 and 2002, the UDF acted as the successive Gaullist parties' main coalition partner.
} 
Mitterrand and Prime Minister Edouard Balladur. The RPR-candidate Jacques Chirac won the 1995 presidential election, but after he dissolved the Assembly in 1997, the alliance between the PS, Greens and Communists obtained a parliamentary majority and formed a government under the leadership of Lionel Jospin who remained prime minister until 2002 (the third and so far last cohabitation experience).

During the 1990s, two transformations in the party system progressively put an end to the bipolar order that had structured French politics since the 1950s. A first noticeable evolution is the decline of the Communist party: while this party attracted close to $21 \%$ of the vote in the first ballot of the 1978 legislative elections, it progressively declined to below 5\% in the 2002 and 2007 elections - and from $15.4 \%$ in the 1981 presidential election to $1.9 \%$ in 2007 . This party was challenged, on the far-left, by multiple challengers (in particular the Trotskyist Lutte Ouvrière and Ligue Communiste Révolutionnaire) that achieved higher scores in the late 1990s and early 2000s. More recently, the creation of the Front de Gauche (now called France insoumise), an electoral alliance led by the Socialist dissident Jean-Luc Mélenchon has given a new dynamic to the far left vote. However, this new party has consistently refused, so far, to enter any coalition with the PS.

In parallel, the Green party has become more relevant in French coalition politics ${ }^{8}$. After breakthroughs in the 1989 municipal and European elections, ecologists received more than $14 \%$ of the votes at the 1992 regional elections ${ }^{9}$. Given this strength and the concomitant decline of the Communists, the Green party imposed itself as a relevant

\footnotetext{
${ }^{8}$ While the party was created in 1984, ecologist candidates and movements have run in French national elections since the 1974 presidential election, with only very limited scores and overall political impact.

${ }^{9}$ There were initially two ecologist parties - the Greens and a less durable party, Génération Ecologie that agreed on electoral alliances for the 1992 and 1993 elections.
} 
coalition partner for the Socialist Party ${ }^{10}$. In 1997, for the first time, the Greens joined the left electoral alliance under the leadership of the PS, which let 29 districts to Green candidates (while the Greens conceded 79 districts to the Socialists, see Boy 2002). This allowed the ecologists to be represented in the National Assembly for the first time and to enter government. Since then, they have negotiated electoral alliances with the PS for each parliamentary election, without success in 2002 and 2007. After the election of Socialist François Hollande for president in 2012, the Greens entered the PS-led coalition government.

Transformations occurred also within the right-wing bloc, in particular with respect to the relations between centrists and conservative parties. These two political families have built a durable electoral alliance, but have also challenged each other within the right-wing bloc. This relation was embodied in the 1970s by the competition between the centrist president Valéry Giscard d'Estaing and Jacques Chirac, who respectively founded new parties, the UDF and the RPR. Each of the two parties have most often presented their own candidate to the presidential election. This division was partially bridged after the 2002 presidential election with the creation of UMP, which aimed at gathering moderate right-wing parties around President Jacques Chirac (Haegel 2002; Sauger 2008). Most of the UDF office-holders joined the UMP, even though the UDF continued to exist and managed to maintain its own parliamentary group. In 2007, its leader François Bayrou gathered 18\% of the votes, did not support the UMP candidate Nicolas Sarkozy and founded a new party, the Mouvement Démocrate (MODEM), just

10 At the regional level, the ecologist parties' spatial location along the left-right spectrum and the distribution of seats allowed them to be pivotal in coalition formations on both the left and the right (Brouard 1999). However, the emergence of the Greens took place above all at the cost of the Socialist and the Communist party, which shows that this party was particularly attractive to left-leaning voters. On the influence of local-level coalitions on national coalition politics, see Bué \& Desage 2009, p. 21-22. 
after the election. This new party was supposed to break-up France's bipolarization and be independent from left and right ${ }^{11}$ but it has so far failed to conquer a pivotal position: only rightwing parties consider this party as a potential coalition partner.

The rise of the radical right National Front (FN) is undoubtedly the most important evolution in French politics over the last three decades. Following the pioneering work by Grunberg and Schweisguth (1997), many scholars have observed that the French political space is no longer bipolar, but structured in three blocs: left, right and far-right, embodied by the FN. This party made a break-through in the 1984 European elections, gathering close to $11 \%$ of the votes, and obtained 35 parliamentary seats at the 1986 parliamentary elections, favored by the proportional voting system adopted by the Socialist government (and immediately abolished by the next government). The FN has since attracted a growing number of votes in national, local and European elections. The party often remains in the second ballot of two-round elections, which perturbs significantly the functioning of the majoritarian logic of the Fifth Republic, in particular regarding the building of majorities at several levels. Following the 1986 regional elections, no absolute majority was found in several regions: in five of them, RPR-UDF presidents were elected thanks to the votes of FN regional councilors (and alliances with the FN were decided in further regions). The acceptability of alliances with the FN was hotly debated within the RPR over the next decades and there have been multiple examples of alliances at the local levels until the late 1990s. Since the 2000s, this type of alliance has no longer occurred. Most of the RPR (and, then, the UMP's) leaders' indeed rejected these alliances on ideological and moral grounds, even though it often implied

\footnotetext{
${ }^{11}$ As a reaction, those in the UDF disapproving F. Bayrou's line founded the Nouveau Centre as a Center party supporting the right-wing presidential majority (see below).
} 
losing the constituency election. The FN adopted, itself, a strong line criticizing the collusion between mainstream parties and did not send any signal of interest in coalitions with the UMP. Its participation to the second round of many local elections, with scores suggesting its capacity to win the election, regularly raises the question for socialists and conservatives to mutually withdraw their candidate.

In the 2002 presidential election, the FN candidate Jean-Marie Le Pen eliminated the Socialist candidate Lionel Jospin from the second round - Jacques Chirac was then elected with over $82 \%$ of the vote. In 2007, the right-wing candidate Nicolas Sarkozy strategically took up the FN's issues - mostly immigration -, which first proved successful in diminishing the FN electoral success (Martin 2010). However, the FN has since then achieved historically high scores at the 2014 municipal and European elections, and again at the 2015 departmental and regional elections, before making it once again to the second round in the 2017 presidential election and reaching the first place at the 2019 European elections.

The French political space is hence more two-dimensional than ever. French voters' attitudes and party competition are not only structured by the traditional class cleavage (essentially linked to the conflict between neoliberalism and interventionism), but also by a second dimension related to globalization and international openness, focused on immigration, European integration, globalization and moral issues (Bornschier \& Lachat 2009; Stimson et al. 2010; Tiberj 2012; Gougou \& Labouret 2013). Mainstream parties (and their traditional coalition partners) have appeared to be internally divided on those two conflict dimensions - the PS especially on economic issues, LR especially on cultural issues. Yet, until 2017, coalitions were based on ideological proximity on economic matters. Coalitions founded on issues of internationalization and morality had never been 
considered, although some discussions took place about the desirability of a left-right convergence of those who agree on liberal reforms and the principle of international openness. This changed following the 2017 presidential election.

This election represents a landmark in party system change in France since it saw none of the candidate from the two main parties (PS or Gaullists) make it into the second round $^{12}$. For the first time, four candidates - Emmanuel Macron, who had founded a new catch-all party, La république en marche (LREM), Marine Le Pen (FN), François Fillon (LR) and Jean-Luc Mélenchon (FI) - came neck and neck in the first round. This suggests a political space divided into four even blocks embodying strictly distinct policy alternatives: Emmanuel Macron and LREM advocate liberal policies on economic and cultural matters, in sharp contrast to the FN which opposes immigration as much as economic globalization. Les Républicains, under the leadership of François Fillon, campaigned for neoliberal reforms and moral conservatism, while Jean-Luc Mélenchon adopted traditional leftwing positions in favor of redistribution and government intervention in the economy (see Gougou and Persico 2017 for a correspondence analysis). Emmanuel Macron benefited from the "republican front" uniting the majority of voters anxious to keep the FN out of power. Without surprise, he obtained a clear-cut victory in the run-off, appointed Ministers leaving the PS and LR in government, and obtained a large parliamentary majority a month later (Elgie 2018). The 2019 European elections confirm the changes discussed, with the FN and LREM confirming their predominance, the Greens achieving able to attract a considerable share of votes, while traditional government parties did not reach $10 \%$ of the votes.

\footnotetext{
${ }^{12}$ In contrast to previous elections, in which they usually attracted more than half of the votes in the first round of the presidential election, their cumulative score fell to only $26 \%$ in 2017 - with the Socialist party gaining only $6.5 \%$ of the vote (Gougou and Persico 2017).
} 
Electoral alliances and pre-electoral coalitions

[TABLE 7.1b about here]

In the French context, two forms of alliances exist in view of parliamentary elections. The most ambitious one, referred to as "pre-electoral coalition" in Table $7.1 \mathrm{~b}$, involves a repartition of districts (mutual withdrawal between candidates from the same preelectoral coalition for the first round). In such alliances, candidates might even run under the flagship of all parties forming the coalition (e.g. the Socialist party and the Greens). This indicates the willingness to form a government coalition, even though this is not always formalised or explicitly communicated. The second form of electoral alliance ("electoral alliances" in Table 7.1b) is limited to mutual withdrawal for the second round. This reflects the belonging to the same «block »: without such withdrawal, the chances of the other block to win the election would indeed be much higher ${ }^{13}$. In many cases, coalition agreements are not explicitly subject to public communication by the parties, and the actual figures of mutual withdrawals never appear in coalition agreements.

The first electoral alliance emerged within the left-wing block, when Socialists and Communists agreed on mutual withdrawal for the second round of the 1962 parliamentary elections. This agreement was renewed for the 1967 and 1968 elections. In 1973, a further step was taken with the adoption of a common governing programme (Le programme

13 Accordingly, mutual withdrawal in the first round is coded in Table $7.1 \mathrm{~b}$ as an electoral alliance associated to a pre-electoral coalition, while national-level agreements on mutual withdrawal for the second round are coded as an electoral alliance only. Note that local-level agreements, which are very frequent, are not listed in the table. 
commun) and the mutual withdrawal of candidates from both parties before the first round. The Movement of Left Radicals, a splinter party from the centrist Radical Party, joined this alliance and, contrary to the Communist party, has since then never ceased to form pre-electoral alliances with the Socialist Party. As shown by Table $7.1 \mathrm{~b}$, the relationship between the PC and the PS has fluctuated. While the agreements between both parties in 1981, 1986, 1988 and 1993 were limited to a mutual withdrawal for the second round, due to programmatic divergences, both parties, along with the Greens and the Left Radicals, reached an agreement for mutual withdrawal for the first round in 1997. Since 1997, both parties have never reached any formal electoral agreement.

The Greens have also not entered electoral alliances in 2002 and 2007 but have reached an agreement with the PS regarding office and policy in 2012, as did the left radicals. Following François Hollande's presidential victory, the PS built an oversized coalition with his two partners. Multiple policy conflicts opposed the PS not only to its left factions, embodied by ministers like Arnaud Montebourg or Benoît Hamon, but also to the ecologists. Green Ministers Cécile Duflot and Pascal Canfin decided end to their government participation in March 2014, when François Hollande appointed a new government following the majority's defeat at the municipal elections. Green MPs and left PS factions (les frondeurs) became increasingly mobilized against government policies. In August 2014, this motivated the appointment of a new government designed to be more cohesive around François Hollande's moderate positions. In February 2016, at the occasion of a government reshuffle, three former leaders of the Green party among others the Secretary General Emmanuelle Cosse - left the Greens to join The Ecologist Party, a splitter party from the Greens formed shortly before, and joined the PS-led government. These deep divisions within the left-wing block explain part of the 
result of the 2017 elections. After the socialist primary election appointed Benoît Hamon, a leading figure of the frondeurs, the PS reached a coalition agreement with the Greens including, for the first time, the withdrawal of the Green candidate from the presidential election. Yet, Hamon's social and environmental political line was not supported by the liberal factions of the PS, which turned to Emmanuel Macron, paving the way to Macron's victory and for Hamon a disastrous score.

Electoral alliances within the right-wing block also go back to the 1960s. Since 1967, Gaullist parties - de Gaulle's UNR, the RPR, the UMP and LR - have often formed electoral alliances with liberal and/or more centrist parties. After 1978, electoral alliances and coalition agreements gathered the Gaullist party RPR and the centrist party UDF. This foundation of the UMP translated into the fact that governments formed under Jacques Chirac's second presidential mandate (2002-2007) were no coalition governments but comprised only UMP ministers and a few non-partisan personalities. Under Nicolas Sarkozy (2007-2012), governments reflected the surplus coalition between the UMP and the Nouveau Centre, founded in 2007, to gather centrists within the presidential majority (initially with the financial support of the UMP), while the Modem refused to enter right-wing coalitions. François Bayrou supported Emmanuel Macron in the 2017 campaign, quoting four blurred policy priorities to justify his support. After Macron's presidential victory, his party LREM reached a pre-electoral agreement with the Modem, which implied no policy implications but was limited to a mutual withdrawal on most constituencies, LREM supporting Modem candidates in 75 districts.

As noted by Thiébault (2003), French electoral alliances are more the product of electoral necessity than of genuine affinities between the parties. If they want to enter government, junior coalition partners have no choice but to agree on electoral alliances 
with one of the biggest parties ${ }^{14}$. This asymmetry shapes French coalition politics. In particular, coalitions are not negotiated collectively by all political parties involved, as in many other countries, but take the form of bilateral agreements between the leading (mainstream) party and each junior partner.

\section{Government formation}

As Bedeï formulates it, "in France, government composition goes down to a weird and unlikely formula including unpreparedness and chance" (2015: 9-10). When thinking about French peculiar government formation ${ }^{15}$, three distinctive features stand out. First, presidents - prime ministers in times of cohabitation - benefit from a great autonomy when selecting cabinet members ${ }^{16}$. Second, pre-electoral negotiations and agreements, rather than actual electoral results, have a tremendous impact on the power relationships between coalition members. Third, political parties are weak: their electoral result only partially translates into a parliamentary balance of power and parliamentarians representing those parties enjoy a very large autonomy. All this means that the president's role in cabinet formation should not be understated (Elgie \& Grossman 2016) and that post-electoral negotiations among parties are reduced to the bare bones.

\footnotetext{
14 Additional incentives derive from French rules of public financing, which represents $40 \%$ of parties' resources on average (François \& Phelippeau 2018). Parties' state subvention is calculated based on their share of parliamentary seats, but also on the number of votes obtained in the first round of the last parliamentary elections - provided the party has received at least $1 \%$ of the votes in at least 50 districts. From the point of view of a small party, having candidates running with the support of a mainstream party therefore brings, beyond the prospect of participating to a coalition government, considerable financial resources.

${ }^{15}$ If France is a special case, similar features, including strong presidential leadership and fluid party politics can be observed in other countries, for instance in Romania.

${ }^{16}$ As Safran puts it, "the Constitution states that the President chooses the Prime Minister and then confirms the selection by the latter of his or her cabinet colleagues. In fact, under normal conditions - that is, if the majority of the National Assembly, and hence the prime minister, belongs to the same political party as the President - the president selects most, if not all, members of government” (2008, p. 201).
} 
The bargaining process

[TABLE 7.2 about here]

While government formation and bargaining depend on the last parliamentary elections' results in many other democracies, it starts much sooner in France and does not last very long after the elections. Following presidential elections, all presidents have appointed a new government, even when they did not have a parliamentary majority during the few weeks leading to the parliamentary elections. As appears in Table 7.2, bargaining duration is short on average - less than two days - and government are formed after the first single round of negotiation (which are not even real negotiations as we will explain below). Amongst the few exceptions, the Messmer II and III's, Mauroy I's, Rocard II's and Valls I's government formations have necessitated more than 5 days of bargaining and/or two rounds of negotiations. In these cases, contrary to most other governments, the withdrawal of former coalition parties after a reshuffle, or the hesitations of a potential coalition member led to some uncertainty regarding the exact perimeter of the coalitions. Even then, government formation never required more than 17 days.

The reason for this rapid government formation process is to find in the pre-electoral nature of coalitions. The power relationships between coalition members do not really depend on their latest electoral performance, because this performance is influenced by how political parties viewed this power balance during the pre-electoral negotiations. Indeed, the number of districts reserved to each coalition parties, and hence the number of elected MPs depend on pre-electoral considerations. Pre-electoral negotiations hence 
partly determine the composition of the majority in parliament and in cabinet, at least by clarifying which parties will take part to the coalition.

When the pre-electoral agreement involves mutual withdrawals for the first round and a plan to govern as a coalition, two rounds of negotiations take place separately, dealing respectively with (1) the district repartition among parties and (2) programmatic agreements. The distribution of ministerial portfolios is not subject to interpartisan bargaining before the elections. Our qualitative interviews with (former) party leaders and ministers from all governments since the early 1980s have revealed that all parties do not grant the same importance to programmatic and office considerations. For example, Greens and Communists can be seen as more policy seeking, while Left radicals or centrist parties, which happen to be located closer to the PS or the UMP in terms of policy positions, tend to put more emphasis on office-related considerations. Mainstream parties such as the PS are mostly office- and vote-seeking: they have strong incentives to build electoral alliances with as many small parties in their ideological block as possible to maximize their chances to obtain a majority of votes in many districts.

How much are mainstream parties ready to pay for such coalition agreements? The final answer is hard to provide, given party officials' reluctance to provide precise information on the content of electoral agreements. These agreements do indeed carry the negative image of partisan arrangements - they are seen as deals behind closed doors to defend each party's interests. Yet the role of the main party in the coalition is tremendous. Symbolically, negotiation talks between leftwing parties tend to take place in the PS headquarters. More importantly, many negotiations have failed because the main party of the coalition (the PS or the Gaullist party) did not leave enough seats to its coalition partners. Even when an agreement is reached, those mainstream parties might not succeed 
in having it respected everywhere. Withdrawn local candidates may run as independents, hence hindering the chances of the coalition candidates. For instance, the Green party's current leader and former negotiator David Cormand estimates that, in 2012, some 20 out of 65 districts reserved to the Greens witnessed dissident candidacies from the PS.

Nevertheless, the consequences of these electoral agreements - the actual electoral results - hardly affect cabinet composition. Had they managed to get 10 more MPs, the Greens would probably have had the same number of ministers in Ayrault's government. Electoral outcomes are not shaping the composition of government through the definition of a parliamentary balance of power, as in a pure parliamentary system: they are not exogenous insofar as they strongly depend on coalition negotiations and related electoral agreements. In this context, the president and his party are very prevalent in forming the coalition.

The composition and size of cabinets

[TABLE 7.3 about here]

Once the elections have passed, government formation in France is different from pure parliamentary systems. In the absence of cohabitation, the president leads the negotiations mostly together with the new prime minister. Discussions take place informally with individual officials from the parties in the coalition, who are discretionarily offered ministerial positions. While composing the government, presidents and prime ministers do not only consider coalition-related arguments but also try to represent ethnic, gender, territorial origin and age (Bédéï 2015). Since no collective bargaining among parties really takes place, junior parties can hardly influence the 
number of ministers they will be granted, the nature of portfolios allocated, let alone the overall composition and size of cabinets. The bargaining process rather takes the form of a "take-it" or "leave-it" proposal by the main government party (in fact, the President or the Prime Minister), with little margins for manoeuver for coalition partners. Our interviews suggest that they are not even in the position to suggest the names of party officials they would like to enter government. It has, however, happened that party leaders vetoed the proposed appointment of a personality for minister.

As a result, the decision over the number of allocated portfolios rests on the President. Table 7.3 illustrates how the number of portfolios has evolved over time. While the number of Ministries has remained rather stable -around 20 - for most of the period, variations are mostly due to the president reshuffling the cabinet within the same term ${ }^{17}$. Reshuffling allows the president or the prime minister to increase the participation of party factions or junior parties that might otherwise be too vocal against the government. This is no surprise, then, that it most often leads to an increase in the number of ministries.

This also leads to an increase in the number of government level appointments. Most of the time, those new positions are junior positions (called Secrétaires d'Etat, State secretaries), which were not accounted for in Table 7.3, but they can also be full delegated minister positions ${ }^{18}$. The latter are cabinet members. Apart from the inflation linked to reshuffles, the number of cabinet members also tends to be higher during surplus coalitions and in left-wing governments compared to their right-wing counterparts. This

\footnotetext{
${ }^{17}$ Reshuffling is a very common practice under the Fifth Republic. Presidents tend to use government reshuffles as a way of improving their popularity (Grossman 2009) even though this does not always prove effective.

${ }^{18}$ Although delegated ministers do not control any independent administrative structure, they were counted as ministers because they can be entitled to participate in the council of ministers, while Secretaries of State do not (they assist to the meetings only when their competences are on the agenda).
} 
might derive from left-wing coalitions associating more parties on average and/or with the PS split into multiple rival factions seeking representation in government. Finally, the most recent evolutions in cabinet composition point towards a reduction of the number of cabinet members. Although all presidential candidates since Jacques Chirac had pledged to limit the size of the cabinet, this had not been fulfilled up until recently. The Valls, Cazeneuve and Philippe cabinets' size would seem to indicate that this is now the case.

When assessing the composition of cabinet, two features stand out. First, as in many other democracies, the number of women has increased over time, and has even reached 50 per cent in the Philippe II's cabinet. Yet, women more often hold junior positions (Secretaries of state) below cabinet status and only seldom take charge of the most important ministries such as the Interior, Justice, Defence, Foreign Affairs, or the Economy (see Table 7.3 and Grossman \& François 2013). Second, the number of ministers with no previous political background has remained quite low. The same goes for "independent" ministers. The proportion of ministers who were members of parliament varies, but rarely falls below 60 per cent (Grossman \& François 2013).

\section{The allocation of ministerial portfolios}

As mentioned previously, the constitution does not prescribe the number of ministers and the allocation of competences. Consequently, coalition bargaining might concern not only the parties involved in government, but also the distribution of portfolios and competences. However, as for most other dimensions of coalition politics in France, the chief of the executive has an overwhelming power in that regard.

This explains the considerable variations in the number and content of portfolios over time. Listing the more or less permanent ministerial departments in France proved impossible since the ministerial organizational structure is extremely dependent on the 
actual minister's nominations (Siné 2008). The perimeter of each ministry is instable and dependent on what the cabinet looks like, but the ministries listed in Table 7.3 belong to the most stable ones, with a relatively consistent denomination.

Obviously, coalition parties aim at getting a high number of important ministerial portfolios and other non-ministerial positions in government (ministerial chief of staff, councillors...) but their influence on the final decision is limited. The way the Greens entered government in the 2012 Ayrault I cabinet offers a good example of this. After signing a pre-electoral agreement in November 2011, they knew that they would enter government if François Hollande won the presidential elections, but no negotiations took place before the first round of the presidential election, that is, less than two weeks before the government was proclaimed. Even so, the negotiations were very informal and the first-rank Green party leaders ignored the portfolios their party would obtain at the end of the process. They were confident that the party would most probably get two members, one full minister and one Secretary of State, and tried with some success, to influence who these cabinet members would be and which portfolio they would receive. As a prominent figure of the Green party told us during an interview, there was a consensus amongst Green leaders to avoid the ministry for the Environment. They thought obtaining another ministry would help the party gaining credibility, by enlarging their issue profile in the eyes of the voters. They managed to negotiate the allocation of the Ministry for Housing to Cécile Duflot. The other green cabinet member, Pascal Canfin, received the development portfolio under the supervision of a socialist minister for foreign affairs. Prime Minister J.-M. Ayrault informed the two future ministers and the party leadership about the content of their portfolio just hours before the government was announced. 
Portfolio allocation is thus not significantly influenced by junior coalition members. Sometimes, when they get a full ministership position, the PM's or President's party also get a junior position, a state secretary or a delegated minister, in the same ministry, hereby serving as a "watchdog". ${ }^{19}$ Conversely, junior coalition parties that obtain secretaries of State to a ministry controlled by the main coalition party are not in the position to act as "watchdogs" and have no way of monitoring the action of their senior Minister. They can rather be considered as "minister's pet" since they have to conform to the President's, the PM's, or the senior Minister's wishes (Thies 2001). Other considerations rule over the allocation of junior ministries. Some Ministries are often attributed to Ministers with no previous political experience - and hence representing no coalition party - but a strong professional competence. The Ministry for the Economy - with former CEOs - and the Ministry for Culture - with former authors, a former director, and a former publisher are good examples of this. Emmanuel Macron and Edouard Philippe tried to go further in that direction: in the Philippe cabinet, 10 Ministers emanate from the civil society and were selected based on their competence and field experience. This differs from the usual dynamics: as Huber and Martinez Gallardo (2004) have shown, France can be characterized as a country with low levels of Ministers' experience.

\section{Coalition agreements}

[Table 7.4 about here]

\footnotetext{
${ }^{19}$ In Table 7.5, we do not record the actual practice of "watchdog' junior ministers; instead, we code "no". This is because such junior ministers are not included in formal coalition agreements. This is different from the coding for other countries, where the actual practice is recorded.
} 
An important part of the pre-electoral agreement rests on the number of mutual withdrawals allowing parties wishing to form a coalition to be represented in parliament. Our interviews pointed out that negotiators deal more with office- than with policyconsiderations. Yet, the electoral agreement is rarely made public. Documents presented in Table 7.4 hence mostly limit themselves to policy agreements. This table shows how diverse those agreements can be. Most of them are very short while others are longer without though reaching the length and the level of detail of coalition agreements in pure parliamentary systems. There is no straightforward explanation for these differences. Rightwing parties tend, but this is not always the case, to publish shorter documents. Moreover, 1997 agreements were very short, which is due to the fact that early legislative elections were not anticipated, and negotiations for the next elections had hardly started when Jacques Chirac dissolved the Assembly.

Parties' strategies regarding the content of those documents also differ greatly. The Greens have notably tried to gain concessions from the PS in terms of environmental policies. They negotiated the abandonment of the Superphenix nuclear reactor and of the digging of a new canal between the Rhin and Rhône rivers in 1997. The same goes with the decrease of nuclear energy production in 2012. However, they did not always achieve their goals: in 2011, the PS refused to abandon the contested airport project at NotreDame-des-Landes and the building of a new nuclear reactor at Flamanville, and the published coalition agreement highlighted those disagreements (Deront et al. 2018). Communists' and Greens' pressure also led to the decrease in weekly working hours by the Jospin government, as well as the extension of public medical insurance for immigrant and poorest citizens (couverture maladie universelle). The 1997 coalition agreement included those pledges. 
However, most policy agreements are laconic. The Left radicals and the liberals (UDF) have never granted much significance to it; it is hard to recall major policy pledges for which they really fought. Our unsuccessful tentative of collecting all coalition agreements gave us evidence of this lack of interest ${ }^{20}$. In any case, those coalition agreements are not as central in the French context as in others. ${ }^{21}$ They are written well before the election and are not binding. For instance, the Jospin government stuck to its key commitments towards the Greens on environmental matters, but did not respect the negotiated line on immigration, security and hunting for example; the participation of the Communist party in government did not either prevent the government to privatize public companies in an unprecedented rhythm in French history (Cos 2018). The same goes for the closing of the symbolic Fessenheim nuclear plant, which socialists agreed upon in 2011, but was never achieved in the 5 following years.

All party officials encountered for interviews pointed toward the insignificance of coalition agreements. With respect to the coalition between UMP and Nouveau Centre (2007-2012), N. Sarkozy's future cabinet director for instance explains: "I don't remember how the "agreement" was formalized [...]. We agreed on amendments to the UMP's initial legislative project. I then had to draft a note to N. Sarkozy to keep him posted. [...] We then translated this into public documents including online communication and leaflets. It is also possible that a synthesis meeting took place between N. Sarkozy, F. Fillon, their advisers and F. Sauvadet and Hervé Morin [leaders

\footnotetext{
${ }^{20}$ Three missing agreements still have to be located: (1) UDR-RI-CDP for the 1973 election, (2) RPR-UDF for the 1978 election, and (3) the agreement for the 1981 election (between the Socialists and the Communists and/or between the Socialists and the Left Radicals. As regards the 2007 coalition, the former President chief of staff confirmed that the coalition agreement, if it has ever existed, was never made public.

${ }^{21}$ See Bué 2009 for congruent observations with respect to local-level policy agreements.
} 
of the NC] to "record" the amendments and I suppose that in this meeting, we talked about everything except this government agreement about which nobody cared."

Finally, the manifesto of the presidential winner, which is often written after the coalition agreement, gets way more attention in the campaign and serves as the real benchmark for pledge fulfilment (Guinaudeau \& Persico 2018). In contrast, coalition agreements are hardly noticed and do not provide any significant resources for junior coalition members during the term.

\section{Coalition governance}

French coalitions have no formal and hardly any informal coalition governance arrangements. The power of coalition parties once in government is highly asymmetrical. Junior coalition partners and their Ministers have scarce means to encourage the implementation of the coalition agreement. The chief of the executive and the main party of the coalition, on the other hand, enjoy extensive leverage in policymaking and usually manage to get their way. Coalition coordination is hence very informal, and rests on the central role of the chief of the executive, and of individual Ministers' or other key figures' ability to defend their party's interests. To do so, they may either use public communication to highlight disagreements and defend their positions in the public arena, or exert internal pressure through inter-ministerial coordination meetings (cabinet committees) or informal discussions with the members of the executive (Weil 2004). Overall, most of the interviewees we met to write this chapter - former Ministers, chiefs of staff and party leaders - agree that coalition agreements do not constrain governmental action and that the discretion of individual ministers override coalition-related consideration. 
[TABLE 7.5 about here]

\section{The role of individual ministers in policymaking}

As for most other aspects of coalition politics, the chief of the executive (President or Prime minister in times of cohabitation) enjoys an extensive power in policymaking, making France a clear case of dominant Prime Minister model (Dunleavy and Rhodes 1990; Laver and Shepsle 1996; Bergman et al. forthcoming). He does not have to (and rarely does) consult other parties over what should be done: exceptions can be found after great focusing events (e.g., the November 2015 terrorist attack), when President Hollande consults all parties, thereby sending a signal of national unity. Apart from these rare moments, most of the difficulties, for the president, are about accommodating the personal sensibility of each individual minister. We speak of "personal sensibility" since many ministers have a distant relationship with their parties. They are free to act independently rather than bound by their partisan affiliation. This explains why parties' rank-and-files are often quite critical against their party's governmental participation and against their own party's ministers. As we will see below, however, being strongly supported within its own party is a resource a minister can use in case of disagreement with the chief of the executive's decision.

Policy divergences sometimes emerge between coalition partners, mainly with ministers from parties with strong programmatic claims (e.g. Communists and Greens). Both parties have had a tradition of criticizing some of the decisions taken by a government to which they participate (Duflot 2014; Fiterman 2005; Voynet 2003). In contrast, other ministers from the leftwing tend not make strong policy claims and instead 
comply with the president's leadership. Center-right ministers also have the reputation of being submissive to the chief of the executive.

Beside the action of ministers from other coalition parties, the chief of the executive controls that of the presidential party's members. For example, many of the ministers challenging F. Hollande and his successive prime ministers after 2012 belonged to the socialist party (e.g., the industry minister A. Montebourg, or Education minister B. Hamon). Those ministers represented a similar challenge to F. Hollande's decisions as the Green housing minister C. Duflot, who was particularly vocal. The history of the Fifth Republic is filled with names of prominent ministers able to mark their differences with the government's policy choices: J.-L. Borloo in the Fillon cabinet, N. Sarkozy in the Raffarin cabinet, or L. Fabius in the Jospin cabinet are all good examples of such ministerial counter-powers.

The role of individual Ministers in policymaking hence depends on whether they agree, or not, with the chief of the executive. If they agree, they can have some leeway to implement consensual policy choices. If they do not, their ability to influence policymaking depends on their individual leverage - which, in turn, reflects their previous political weight (faction or junior party leaders, former Ministers...), their public popularity, the importance of their ministry (e.g., economy, interior), itself correlated to their protocolary (status) order. In case of strong disagreement, interviewees consistently cited the request to meet the president or the prime minister as the primary way to seek policy concessions. But all also agreed that this instrument can only be used with moderation. In this respect, a former green minister, explained that ministers have to define a little number of "red-lines" on which to feel legitimate to ask for a meeting with the chief of the executive. He also emphasized that going public was a risky strategy open 
only to politicians with considerable political weight. This might explain why E. Macron and E. Philippe decided to form a government with secondary political figures, mostly unknown to the public and/or deprived of any strong partisan support.

Without political weight, going public over a disagreement with the chief of the executive is politically risky. D. Batho, a former environment minister in the Ayrault cabinet, was for example fired immediately after she openly criticized budgetary decisions in 2013. Many ministers think they should never communicate on their disagreements. Remaining might mean being less influential in policymaking, but cases of ministers winning their argument against the president or the prime minister are rare anyway. J.-P. Chevènement, a former leader of the main leftwing faction of the socialist party and the founder of a splitter party, who resigned from both the Mauroy and Jospin cabinets, famously declared: “As a minister, either you shut up or you resign'.

\section{Coalition governance in the executive arena}

No law has ever been passed against the chief of the executive's will - or that of the president when there is no cohabitation. The president's power of assembly dissolution makes him a key actor - through the (implicit) threat of dissolution - in coalition management (Elgie 1999). The situation has never occurred, but one can imagine that a president facing the adoption of a law he does not want would consider dissolving parliament and calling new elections. This may be regarded as a form of informal veto power. Similarly, there is no de jure right for the president to initiate legislation but, de facto, the president is (in particular outside cohabitations) the initiator of many laws passed. He enjoys a large presidential cabinet with highly qualified councilors affected to most policy area and is therefore able to follow the legislative and governmental processes very closely. 
The prime minister is clearly not in full control of the governmental agenda. Even regarding the most formal institution, the Council of ministers, his proposition has to be agreed on by the president (the PM proposes, the president decides). The president always presides the Councils of ministers in the Fifth Republic (i.e. also in times of cohabitation). He may use these meetings to get information about government policies and even to exert forms of veto. On some topics, the president may ask each minister to express his or her opinion. However, all interviews confirm that no decisions are made in the council of ministers, but in previous informal negotiations among ministers under the leadership of the PM and/or the President. The council of ministers is a formal enumeration of decisions already made; press releases are ready before the actual meeting.

Several other structures allow the Prime Minister to monitor governmental action: the government's general Secretary; the general secretary for European Affairs; the general Commission for Prospective and Planning and the Government Information Service - which is not only providing expertise and analyses, but also organizing the public communication on government policies ${ }^{22}$. These structures are mainly composed of high civil servants but also possibly of political appointees and provide valuable information to the prime minister, who has the final say in inter-ministerial disputes.

Table 7.5 shows that coalition members can rest upon few conflict management mechanisms in the executive arena. Cabinet committees (inter-ministerial meeting) are the most commonly used mechanism of the sort, even though they mostly try to find a compromise between two ministries over a policy dispute, regardless of the partisan affiliation of the Ministers. Some cabinets have tried to use other ad-hoc conflict

\footnotetext{
${ }^{22}$ An interview with a former director of this service revealed that it also works closely together with the presidential cabinet.
} 
mechanisms, which, however informal and temporary they may be, can be compared to mechanisms in use in other democracies. For instance, under Edouard Balladur's and Alain Juppé's prime ministership, parties in government decided to meet on a regular basis in coalition committees. During the Jospin government, most prominent figures of the majority were invited in weekly "majority breakfasts", where current affairs were discussed collectively. Yet, such initiatives rarely lasted the whole term, and never profoundly influenced the actual decision-making process.

Our interviews suggest that some conflicts within government are not settled at all. At the end of the day, the president - and his cabinet advisors - have the final say and the practice of asking for a meeting with one of them in case of strong policy disagreement prevents direct confrontation between ministers. A former minister of the Interior explained in our interview that he strongly opposed the minister of planning and the environment, on multiple issues. In particular, she asked for the closure of an incineration plant in his home constituency, which she judged not sufficiently safe. The préfet, representative of the State in this region, placed under the responsibility of the minister of the interior, did not comply with her demands. He ironically observed that he had to send the police to oversee public demonstrations backed by his cabinet colleague. Ministers mostly have to accept government policies more or less divergent from their own party line. This is a frequent reason for resigning - which both ministers involved in this episode respectively did.

\section{Governance mechanisms in the parliamentary arena}

Coalition governance mechanisms in the parliamentary arena are also very informal. Most formal instruments relate to governmental stability and the defense of the chief of the executive's policy positions. Junior coalition members can only hope to have their voice 
heard either during informal talks, within parliamentary committees, in the National Assembly, or in the press.

The first encounter between a newly formed government and the parliament provides a good example of this asymmetric relationship. There is no investiture vote in the French Fifth Republic. However, Prime ministers have the possibility to seek a vote of confidence following their "discours de politique générale" (general policy discourse) to the National Assembly. This is the first instrument through which the prime minister can coordinate his coalition in the parliamentary arena, and junior coalition members have no say regarding the content of that general policy speech. The prime minister can voluntarily ask for a confidence vote after having presented his or her general policy discourse which is then equivalent to an investiture vote. This is not compulsory and only governments with a clear majority have done so.

Parliamentary groups hardly influence coalition governance. Although group members select their leaders through a formal election, these leaders tend to support the interest of the chief of the executive, and not necessarily those of their parties. As regards the election of the head of the main coalition party group, it is often just a formal validation of the president's choice: All candidates supported by the president or the prime minister have won the nomination in the end. As regards junior coalition parties' groups, there is also a tendency to select MPs that are rather favorable to the government (e.g. François De Rugy for the Greens in 2012 or Alain Bocquet for the communists in 1997). Some group leaders have managed to take some autonomy towards the president or the prime minister. For example, J.-F. Copé, the UMP group leader under N. Sarkozy’s presidency was a prominent figure of the Gaullist party before taking office and made sure that his and his supporters' positions were defended. 
In France, coalition discipline mostly relates to party discipline and it is not mentioned in any coalition agreement. All interviewees made it clear that there is an implicit expectation (strong convention) regarding party discipline on important - if not all - policies. Parties in parliament can keep their MPs in line through diverse means: they can offer prestigious positions either within the National Assembly (e.g., the leadership of a parliamentary committee), within the party (e.g., the charge of a policy domain), or guarantee the presence of potential defectors' close acquaintances in future second order elections. They may also not renominate potential defectors' for the next parliamentary elections.

A further relevant institutional feature is the existence of strong restrictive legislative procedures in the constitution of the Fifth Republic. In response to the trauma of the important cabinet instability under the Fourth Republic (Huber \& Martinez-Gallardo 2004), linked to the lack of any coherent and stable parliamentary majority, the Fifth Republic was designed in order to rebalance power between executive and legislative powers. The imperative was to enhance the government's policymaking capacity even in the absence of a reliable parliamentary majority (Huber 1996). In particular, the legislative procedures defined in articles 44.3 and 49.3 of the constitution allow the government to pass legislation despite a policy conflict with coalition partners or backbenchers within their own party. ${ }^{23}$ This is a factor of government duration in France - it notably explains that PS-led minority governments could effectively govern over five years (between 1988 and 1993). Those restrictive legislative procedures can offer

\footnotetext{
${ }^{23}$ Article 49.3 institutionalizes a confidence vote procedure. If invoked by the prime minister in the legislative process, the government's bill is adopted unless a majority of legislators votes to censure and bring down the government. Article 44.3 defines the so-called package-procedure (vote bloqué), in which the Assembly has to deliberate on a bill under exclusive consideration of the amendments proposed or accepted by the government (Huber 1996).
} 
unexpected instruments for junior coalition partners, in order to defend their positions. Huber (1996) shows that using the art. 49.3 may also be a way to manage internal disagreement and allow coalition partners to show their disagreement without having to leave the majority. The 2008 constitutional revision has considerably restricted the usage of the 49.3 article which may now be used only once per parliamentary session (the only exception being budget laws, for which there is no limitation). This is likely to reinforce coalition partners' (or factions') bargaining power in case of policy conflict, and/or to reduce government stability.

\section{Other governance mechanisms}

In contrast to pure parliamentary systems, there are overall very few (formal and informal) coalition governance mechanisms and no instance coordinating government coalitions across the partisan, the executive and the legislative arenas. As already mentioned, coalition agreements focus on general policy orientations and do not state any conflict management mechanism. This is probably a reflection of the de facto predominance of the main government party, junior parties having virtually no other leverage, once elections are passed, than the threat to leave the coalition. In the absence of any reform of the majoritarian electoral system, there is no tendency towards a tighter monitoring of coalition agreements' enforcement.

Overall, political parties appear to be weak actors in government policymaking, as in other dominant Prime Minister models. Junior parties (but also minority factions within mainstream parties) are more vocal and try to influence the government's policy line on the issues that matter most to them. Rank-and-files are often more critical about governmental participation and less prone to policy concessions, but this rarely had any impact. As already exemplified, small parties face a dilemma between participating to 
government and having to accept numerous policy compromises that are not negotiated in advance, or remaining in the opposition in which the electoral system and the constitution provide them with only little resources.

\section{Cabinet duration and termination}

\section{The duration of cabinets}

After the spectacular instability of the Fourth Republic, the constitution of the Fifth Republic was meant to create the conditions for stable and effective governments, with a majoritarian electoral system and comparatively strong restrictive legislative procedures. These objectives were achieved, since governments appear as more stable, with an average duration of more than 20 months. This average is not fully representative of reality because it is biased by the practice that newly elected presidents immediately appoint a new (usually very similar) government which ends a few weeks later, after legislative elections have taken place (see above): leaving these caretaker governments out, cabinets serve more than 700 days (i.e. 23 months) on average.

The termination of cabinets

[TABLE 7.6 about here]

The main cause for cabinet termination, as illustrated in Table 7.6, is the occurrence of regular legislative or presidential elections. In one instance (in 1997), legislative elections followed the dissolution of the National assembly by president J. Chirac. A second important cause is government reshuffling, used by the President to increase his popularity (see Section 3 above). Examples of this strategic reshuffling are the 
termination of the Mauroy government following massive mobilization against a bill on education policy in 1984, the replacement of prime minister Edith Cresson with Pierre Beregovoy in 1992, Jean-Pierre Raffarin's resignation after losing the 2005 referendum on the European constitutional treaty or the end of the Ayrault government in 2014, after the PS suffered considerable losses at the 2014 municipal elections.

Overall, ministerial tenure usually ends due to collective reasons $(80 \%)$ rather than to ministers' individual motivations or to conflict within coalitions. In keeping with this, French history has witnessed junior coalition partners leaving government against the background of strong policy disagreement. Note that even when this is not the apparent cause for government termination, reshuffling might open a window of opportunity for dissatisfied parties to leave the coalition. This occurred for example in 1984, when the Communist party decided not to join the Fabius government formed by the PS after the termination of the Mauroy cabinet. They officially justified this decision with respect to the austerity policies implemented, but there is evidence that electoral sanctions at intermediary elections were also an incentive.

Overall, our observations suggest that policy conflict within coalitions becomes a more frequent cause of government crisis and (sometimes) terminations over time. Our interviews suggest that this is due to junior parties' past frustrations with respect to their limited policy achievements when in government. Many of their representatives are now reluctant to accept compromises. ${ }^{24}$

\footnotetext{
${ }^{24}$ This idea that government coalitions are influenced by past interactions between parties is developed in Franklin and Mackie (1983).
} 


\section{Conclusions}

As we have shown, French coalition politics is distinctive in Western Europe. There is a strongly imbalanced power structures in favour of the party of the President (or Prime Minister in times of cohabitation). France is therefore a particular and rather extreme case of dominant Prime Minister Model. The constitution of the Fifth Republic creates strong incentives to build pre-electoral alliances, but the majoritarian electoral system and semipresidentialism have led to an extreme predominance by the main parties, and in particular of the chief of the executive, over their junior partners. Institutional reforms have still reinforced the weight of president. Small parties can exert leverage mainly before the elections, given their capacity to negotiate their support during the campaign and mutual withdrawals for the first or the second round of elections.

Once the election is passed, coalition politics are strongly structured by presidential logics (outside cohabitations) and take place to a large extent beyond parties: individual MPs from the same party may join different parliamentary groups depending on their attitude towards the president. Given the absence of formal coalition governance arrangements, junior parties' resources for influencing government policies are very much restricted to public communication, informal exchanges with the chief of the executive, and the threat to leave the coalition. Modalities of coalition governance provide the chief of the executive (i.e. the president since 2002) with strong leadership, extensive leverage in policymaking and a final say in interministerial disputes. He usually manages to get his way and only rarely consult parties in his coalition. Consequently, these parties will affect policy outcomes only with respect to very emblematic issues (usually one or two) and to the definition of "red lines" likely to be a motivation for terminating their participation to government. Political parties are aware of this and do not expect coalition 
agreements to be implemented - they conceive them at best as a document allowing them to present their agreement as a political project and not as a mere electoral alliance. This situation nourishes considerable frustration within most junior coalition parties.

This context explains recurrent attempts to build large movements gathered around the presidential candidate/president within each bloc. However, this has not succeeded in terms of durability and the party system is increasingly fragmented. Internal divisions and the emergence of a large far-right bloc puts coalitions under considerable pressure. The rise of the National Front, which is until now excluded from the coalitionable parties, reduces the space for building coalitions, while the PS and the Republicans are respectively facing growing difficulties in building alliances and in managing internal dissent. This poses all the more a challenge, as the key tool for insuring government survival in face of policy conflict, the particular French version of the confidence vote procedure, in many cases is not a viable option anymore. 


\section{References}

Andolfatto, Dominique, \& Greffet, Fabienne (2008) 'La 'semi-cartellisation' du parti communiste français'. In: Aucante Y., Dézé Alexandre (eds.) Les systèmes de partis dans les démocraties occidentales. Le modèle du parti cartel en question. Paris: Presses de Sciences Po : 321-346.

Armingeon, Klaus, Virginia Wenger, Fiona Wiedemeier, Christian Isler, Laura Knöpfel, David Weisstanner and Sarah Engler. 2019. Comparative Political Data Set 1960-2017. Zurich: Institute of Political Science, University of Zurich.

Bédéï, Jean-Pierre (2015). Sur proposition du Premier Ministre... Dans les coulisses du remaniement. Paris: Editions de l'Archipel.

Bergman, Torbjörn, Ilonszki, Gabriella, \& Müller Wolfgang C. (forthcoming) Coalition governance in Central Eastern Europe. Manuscript.

Bué, Nicolas (2009) 'Les accords de coalition dans une municipalité d'union de la gauche. Contribution à l'étude de la régulation des rapports coalitionnels'. Politix, n88:105-131.

Bornschier, Simon, \& Lachat, Romain (2009). 'The Evolution of the French Political Space and Party System', West European Politics, 32/2: 360-83.

Boy, Daniel (2002). 'France', Environmental Politics, 11/1: 63-77.

Bué, Nicolas, \& Desage, Fabien (2009) 'Le "monde réel" des coalitions. L'étude des alliances partisanes de gouvernement à la croisée des méthodes'. Politix, , $88:$ 7-37.

Chevallier, Jean-Jacques, Carcassone, Guy, \& Duhamel, Olivier (2004). La Ve République 1958-2004 : histoire des institutions et des régimes politiques de la France. Paris: Armand Colin.

Conley, Richard S. (2007). 'Presidential Republics and Divided Government: Lawmaking and Executive Politics in the United States and France', Political Science Quarterly, 122/2: 257-85.

Cos Rafael (2018) Dénoncer le programme. Les logiques du désengagement électoral au révélateur des privatisations du gouvernement Jospin. Revue française de science politique, 68(2): 239-263.

Deront, Eva, Evrard, Aurélien, \& Persico, Simon (2018). 'Tenir une promesse électorale sans la mettre en œuvre. Le cas de la fermeture de Fessenheim', Revue française de science politique, 68/2: 265-89. DOI: $10.3917 / \mathrm{rfsp} .682 .0265$

Duflot, Cécile (2014). De l’intérieur. Voyage au pays de la désillusion. Paris: Fayard. 
Dunleavyn Patrick, \& Rhodes R.A.W. (1990) Core executives in Britain. Public Administration 68(1): 328.

Duverger, Maurice (1954) Les partis politiquse. Paris: Armand Colin.

Duverger, Maurice (1978) Échec au Roi. Paris: Albin Michel.

Duverger, Maurice (2004) Les constitutions de la France. Paris: Presses universitaires de France, 15th edition.

Elgie, Robert (1999). 'France'. Elgie R. (ed.) Semi-Presidentialism in Europe, pp. 67-85. Oxford University Press: Oxford.

—. (2018). 'The election of Emmanuel Macron and the new French party system: a return to the éternel marais?', Modern \& Contemporary France, 26/1: 15-29. DOI: 10.1080/09639489.2017.1408062

Elgie, Robert, \& Grossman, Emiliano (2016). 'The Study of Executive Politics'. Elgie Robert, Grossman Emiliano, \& Mazur Amy G. (eds) The Oxford Handbook of French Politics, Oxford Handbooks, pp. 677-92. Oxford University Press: Oxford, New York.

Elgie, Robert, Grossman, Emiliano, \& Mazur, Amy G. (Eds). (2016). The Oxford Handbook of French Politics. Oxford Handbooks. Oxford, New York: Oxford University Press.

Evans, Jocelyn A. (2003). The French party system., Vols 1-1. Manchester: Manchester University Press. Fiterman, Charles (2005). Profession de foi. Pour l'honneur de la politique. Paris: Seuil.

François, Abel, \& Phelippeau, Eric (2018). 'Financing of the French political parties'. Mendilow Jonathan \& Phelippeau Eric (eds) Handbook of Political Party Funding, pp. 271-90. Edward Elgar Publishing Ltd: Cheltenham, UK ; Northampton, MA.

François, Bastien (2011). Le régime politique de la Ve République., 5th ed. Paris: La Découverte.

Franklin Mark N., Mackie, Thomas T. (1983) 'Familiarity and Inertia in the Formation of Governing Coalitions in Parliamentary Democracies'. British Journal of Political Science, 13(3): 275-298.

Gallagher, Michael, \& Mitchell, Paul (2008). The politics of electoral systems. Oxford University Press.

Golder, Sona N. (2005). 'Pre-Electoral Coalitions in Comparative Perspective: A Test of Existing Hypotheses', Electoral Studies, 24: 643-63.

—. (2006). 'Pre-Electoral Coalition Formation in Parliamentary Democracies', British Journal of Political Science, 36/193-212. 
Gougou, Florent, \& Labouret, Simon (2013). 'The end of tripartition?', Revue française de science politique, 63/2: 279-302.

Gougou, Florent, \& Persico, Simon (2017). 'A new party system in the making? The 2017 French presidential election', French Politics, 15/3: 303-21.

Grossman, Emiliano (2009). 'The President's choice? Government and cabinet turnover under the Fitfth Republic', West European Politics, 32/2.

Grossman, Emiliano, \& François, Abel (2013). 'Who are the ministers of the Fifth Republic?', French Politics, 11/3: 272-83. DOI: 10.1057/fp.2013.11

Grossman, Emiliano, \& Sauger, Nicolas (2009). 'The end of ambiguity? Presidents versus parties or the four phases of the Fifth Republic', West European Politics, 32/2: 423-37.

Guinaudeau, Isabelle, \& Persico, Simon (2018). 'Tenir promesse. Les conditions de la réalisation des programmes électoraux', Revue française de science politique, 68/2: 215-37. DOI: $10.3917 /$ rfsp.682.0215

Haegel, Florence (2002). 'Faire l'union : la refondation des partis de droite après les élections de 2002', Revue Française de Science Politique, 52/5-6: 561-76.

Huber, John D. (1996). Rationalizing Parliament. Legislative institutions and party politics in France. New York: Cambridge University Press.

Huber, John D., \& Martinez-Gallardo, Cecilia (2004). 'Cabinet instability and the accumulation of experience: the French Fourth and Fifth Republics in comparative perspective', British Journal of Political Science, 34/1: 27-48.

Laver Michael, Shepsle Kenneth A. (1996) Making and Breaking Governments: Cabinets and Legislatures in Parliamentary Democracies. Cambridge: Cambridge University Press.

Martin, Pierre (2010). 'L’immigration, un piège pour la droite?', Commentaire, 132: 1027-36.

Montay, Benoît (2013). 'Le pouvoir de nomination de l'Executif sous la Ve République', Jus Politicum, 11.

Safran, William (2008). The French Polity., 7 edition. New York: Routledge.

Sauger, Nicolas (2008) 'L'UDF et la création de l'UMP'. Aucante Y., Dézé Alexandre (eds.) Les systèmes de partis dans les démocraties occidentales. Le modèle du parti cartel en question. Paris: Presses de Sciences Po. 
Siné, Alexandre (2008). 'Les contours ministériels vus de la LOLF'. Les réorganisations administratives : Bilan et perspectives en France et en Europe, pp. 41-50. Institut de la gestion publique et du développement économique: Paris.

Sponchiado, Lucie (2017). La compétence de nomination du président de la Cinquième République. Dalloz.

Stimson, James A., Tiberj, Vincent, \& Thiébaut, Cyrille (2010). 'Le mood, un nouvel instrument. Au service de l'analyse dynamique des opinions. Application aux évolutions de la xénophobie en France (1990-2009)', Revue française de science politique, 60/5: 901.

Thiébault, Jean-Louis (2003). 'France: Forming and Maintaining Government Coalitions in the Fifth Republic'. Müller Wolfgang. C. \& Strøm Kaare (eds) Coalition Governments in Western Europe, Comparative Politics, pp. 498-528. Oxford University Press: Oxford, New York.

Thies Michael F. (2001). "Keeping tabs on partners: The logic of delegation in coalition governments". American Journal of Political Science 45(3): 580-598.

Tiberj, Vincent (2012). 'Two-axis politics: Values, votes and sociological cleavages in France (19882007)', Revue française de science politique (English Edition), 62/1: 67-103.

Voynet, Dominique (2003). Voix off. Paris, France: Stock.

Weil, Thierry (2004). 'La machine Matignon', Le journal de l'école de Paris du management, 45: 28-36. 